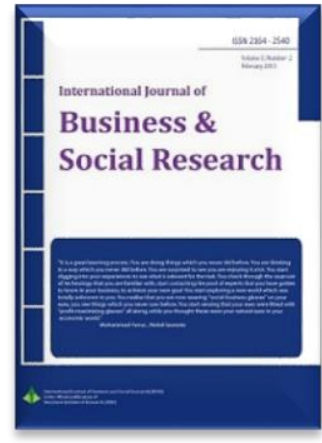

\title{
Tax Stories from South Anatolia
}

\author{
Mesut Sert ${ }^{1}$
}

\begin{abstract}
In this research, the data obtained from the oral history interviews with both sides - tax payer peasants and tax collectors - are used to interpret how tax relations work and how this process is perceived by the tax payer. Based on the idea that nicknames might offer a more realistic framework in this sense, the nicknames given to tax collectors, such as Rıza of the Cliff (Uçurumlu Rıza), Mustafa the Angel (Melek Mustafa), the Slender Tyrant (Ince Zalım), and the Black/Yellow Hell (Kara/Sarı Cehennem), are believed to be a representative of the relationship between both parties. Never published before in another medium, the story of Süleyman, the Butcher (Kasap Süleyman) is also hereby introduced into field literature.
\end{abstract}

Keywords: Fiscal sociology, fiscal history, oral history, tax collector.

JEL Codes: HoO, H2O, H29, H89.

Available Online: 10-05-2016

This is an open access article under Creative Commons Attribution 4.0 License, 2016.

\section{$1.0 \quad$ INTRODUCTION}

After the proclamation of the Turkish Republic, all imperial methods of revenue collection, including iltizam (tax farming) were abolished, and the guiding principle in revenue collection became the individual collection of the revenues by government officials. Because the majority of the country's population resided in rural areas during the early days of the republic and considering the difficulty concerning transportation then, the mounted tax collector proved to be quite significant in the process. However, with the recent improvements in banking transactions and transportation, mounted tax collectors gradually died out in the 1980s. Today, tax collectors work under district revenue departments, and the methods of collection and transportation they use differ greatly from those used in earlier days of the republic. The duty of the tax collector focuses more on notification than on collection today, and they tend to use motorized vehicles.

In this research, the way tax relations function and how the process of tax collection is perceived by tax payers are studied by using oral history method.

\footnotetext{
${ }^{1}$ Department of Public Finance, Akdeniz University, Turkey. Email: msert@akdeniz.edu.tr
} 


\section{0}

Oral history in short, can be defined as the method which uses the memory as a source for historical research. Although "it was the first kind of history" (Thompson, 2000, p. 25), it especially came in to question after the Great Depression in USA as a method of historical research. Its scope has been expanding to cover almost all social sciences and there are literatures both to introduce and how methodology is used - i.e. (Perks \& Thomson, 1998; Danacıoğlu, 2010; Neyzi, 2009).

As a method, Oral History mainly relies on the narrative text which formed with the interviewer and interviewee. After recording videotapes or audiotapes, interview is decoded and interpreted by interviewer with also literature and other source of material to explain research question.

In this research it is interviewed sixteen people at different places and times as shown in following table.

\begin{tabular}{lrrrr}
\hline \multicolumn{5}{c}{ List of Interviewees } \\
\hline Name & Age & Place & Qualification & Date of Interview \\
\hline Osman Aydın & 79 & Manavgat & Tax Collector & August 30, 2012 \\
Mustafa Çakmak & 86 & Gazipaşa & Tax Collector & October 20, 2012 \\
Mustafa Tomruk & 82 & Kaş & Tax Collector & December 22, 2012 \\
Hulusi Oğuz & 58 & Gazipaşa & Tax Collector & October 21, 2012 \\
Necla Duru & 79 & ibradı & Tax Collector Daughter & August 31, 2012 \\
Cazibe Kurt & 69 & Kaş & Tax Collector Daughter & December 22, 2012 \\
Ali Kocaer & 100 & Kalkan & Tax Payer & December 22, 2012 \\
Ali Canbaş & 87 & ibradı & Tax Payer & August 31, 2012 \\
Vahdettin Barut & 86 & ibradı & Tax Payer & August 31, 2012 \\
Hüseyin Gerçek & 87 & ibradı & Tax Payer & September 2, 2012 \\
Ahmet Uysal & 85 & Gazipaşa & Tax Payer & October 20, 2012 \\
Şevket Tanç & 86 & Kalkan & Tax Payer & December 22, 2012 \\
Emin Necati Kırca & 79 & Kalkan & Tax Payer & December 23, 2012 \\
Mehmet Kocasarı & 85 & Kalkan & Tax Payer & December 23, 2012 \\
Sadık Yılmaz & 62 & Kalkan & Tax Payer & December 23, 2012 \\
Yusuf Ustaali & 90 & Kalkan & Tax Payer & December 23, 2012 \\
\hline
\end{tabular}

In order to build a more comprehensive framework, the interviews were carried out with not only tax collectors but also their tax payers. The interviewed tax collectors were selected from among those who are still alive, and when this was not possible, the tax collector's children were interviewed. Whereas four of the tax collectors resided in Manavgat, Gazipaşa, and Kaş, the children of the two other were based in ibradı and Kalkan. As a result of a preliminary survey carried out in where ten of our interviewees lived, it was decided that only those between eighty-ninety years of age who have experienced, and thus still remember, tax-related problems be elected.

After the information regarding their place and date of birth, family origins, level of education, marital and military service statuses was obtained, the interviewed tax collectors were asked to provide information on how they got into the business of tax collecting, where and when they started work, what type of taxes they collected, and significant work-related memories. They were also asked whether they were called names/nicknames by the natives. On the other hand, the interviewed tax payers were also asked to provide similar information on their family origins, their affiliated tax collector, the problems, if any, they encountered while taxpaying, their relationship with the tax collector, and whether they called their tax collector names.

In the following sections, the findings obtained from the interviews are summarized ${ }^{2}$.

\footnotetext{
${ }^{2} \mathrm{~A}$ more comprehensive analysis of the findings is available in the author's previous article.
} 


\section{0 \\ RELATION BETWEEN TAX COLLECTOR AND PEASANTS: WE LOVE EACH OTHER (DON'T WE?)}

Considering the fact that the peasant's main connection to the state is that of tax connection, the relationship between the tax collector and the tax payer is also a reflection of the way the peasant perceives the state.

Based on the interviews, the general feeling from the perspective of the tax collector is that peasants are honest and trustworthy people, which yield a smooth and uneventful communication between the parties. Tax collector Osman Aydın from Manavgat compares the county to the village and says:

There are some who argue against taxes here [in the city], but nobody objects to anything in the village. Peasants are more demure, more alert, and yet more humane. They obey the laws of the state. They wouldn't fox another.

Similar ideas were communicated also by the other tax collectors. Mustafa Çakmak from Gazipaşa shares his ideas as follows:

... the people of this district, Gazipaşa... I've always known them and worked with them for a long time. These people are naive; not well off, but middle-income, let's say. They were never bad debtors. They wouldn't stab you in the back.

Although he does not deny the existence of certain problems, Hulusi Oğuz, from Gazipaşa, in a manner to emphasise the power of the state, says:

There are always a couple of problems in a flock, but this must not be generalised. If only one out of a hundred creates the problem, then this must not be taken into account. No matter how much one objects to it, the state always gets what it is entitled to get. Otherwise, legal proceedings will be commenced.

It is significant that the tax collectors also paid considerable attention to good relations with tax payers; in fact, they even did them small favours by overlooking certain problems. Mustafa Çakmak, underlining that he sometimes turned a blind eye to small things during stocktaking, says:

Well, that's between you and me. You have to condone certain things. You count ten [goats] but record seven or eight. That's alright. I used to say to the tax payer, 'There you go, I'm doing you a favour and record eight animals, but I can't just erase it all'.

Mustafa Tomruk also mentions avoiding late fees sometimes and says:

Late fees do not really function when it comes to accrual. Well, there is this man in the village. I look at him. I can see he is poor and penniless. I just condone the late fee, and that's it. My heart just sinks. I have always been on the side of the peasant because I know what being a peasant is. The state is rich. "Its wealth is like the sea... ${ }^{3 "}$

The answer to the question whether peasants are afraid of the tax collector - who, in a way, is identified with the state itself - is negative from the tax collector's perspective, as would be expected. Almost every tax collector conveys that he was well liked by the peasants and that peasants were not afraid of them. What Mustafa Çakmak, and the tax collector's daughter from ibradı Necla Duru say in this context is almost a summary of the general relationship:

They used to like me. No, I mean, they trusted me. No, they were not afraid of me. They trusted me.

....My father was dear to the peasants of his time. Everybody knew his name and called him Necip Ağa (Agha/Master).

3This is an idiom in Turkish to emphasize richness of state. Whole of idiom is that "government property is like a sea, people who don't eat is a pig" 
From the tax payer peasant's perspective, the most forthright statement probably belongs to Mehmet Kocasarı:

.. Of course, we were afraid. When the tax collector's arrival was announced... the tax collector, the gendarme... It was either the gendarme or the tax collector who came to the village, and, yes, I swear, we were afraid.

Although with a different justification, tax payer peasant Yusuf Ustaali relates similar thoughts:

We were afraid; of course, we were... How can we not be? The man never left the village without taking our money. He [tax collector] used to say, 'I'm not here to visit you as a neighbour.' See? That's it. He was here to collect money and he would say it out loud

\subsection{THE NICKNAME AS AN INDICATOR OF THE COLLECTOR-PAYER RELATIONSHIP}

Another field where the collector-payer relationship can be observed is the nicknames given to the tax collectors in villages. It is also legitimate to say that the nicknames are even better at revealing the true nature of the relationship.

Doubtless a tax collector will avoid talking about it if the nickname is not an innocent one. In this regard, Mustafa Çakmak shares his ideas as follows:

They used to call me Mustafa, the Tax Collector [ Tahsildar Mustafa] in the village. They still do.

On the other hand, Hulusi Oğuz says:

They used to call me the Tax Collector [ Tahsildar], or "the one with the bag."That was the nickname. Because we often had a bag with us.

Only Cazibe Kurt, the daughter of tax collector Ali Rıza Öncü, confirmed and explained, though controversially, why his father was called Rıza of the Cliff (Uçurumlu Rıza). The tax collector's friend, Mustafa Tomruk says:

(Laughs) Well... What should I say? (Laughs) People used to call him Riza of the Cliff; that's it. (Laughs)

On the other hand, his daughter Cazibe Kurt notes:

My father used to be an agile, hardworking man. Yes, they used to call him Vcurumlu. (Laughs).

It was his nickname. He was given the nickname because he was always hardworking.

Thus, it can be asserted that the determinant of the nicknaming process is the relationship built between the tax payer and the tax collector. In this regard, although the nickname might be related with the collector's surname or physical peculiarities, it was mainly influenced by the tax collector's attitude towards peasants.

In the example of Mustafa, the Angel (Melek Mustafa), it is seen that the tax collector's surname is the inspiration. Tax payer peasant Ahmet Uysal relates his memories as follows:

... Melek used to be here. Melek Mustafa. He was also a tax collector. His surname was Melek. They called him Melek, though. He was known to be Meleğin Oğlu/son of the angel], also.

And here is what a peasant says about the nickname:

This Melek never smiled. For God's sake. (Laughs). He never ever smiled... Never smiled. He always kept a straight face. Never would he smile when he was face to face with the debtor. Always kept a straight, solemn face...

Another nickname the Slender Tyrant (Ince Zalım), on the other hand, shows how physical appearance influenced the nicknames. The Slender Tyrant worked as a tax collector in Gazipaşa district during the 1940s. Here is how he is described by a peasant Ahmet Uysal: 
The tax collector. He was from Alanya and was known as the Slender Tyrant by almost everyone. That was his nickname, yes. I don't know his name. He was a man, just like we are... He wasn't evil or something. He used to come over and chat with us. He went around collecting the money, and he only did if he could. We would offer him food with might and main, and he was kind enough to stay and eat with us. Then he would leave. All in all, nothing unusual.

Another tax collector, Mehmet Bozca is reported to be called by the names of either Sarı Cehennem (The Yellow Hell) or Kara Cehennem (The Black Hell) in different accounts. His story seems to clarify why he was called these names. Tax collector Mustafa Tomruk speaks of him and says:

Mehmet Bozca... He was blonde, but an ugly one... (Laughs). That's the problem with him. A bit grizzly. He used to be called The Yellow Hell down here. He used to go to this village called Palamut, and he gathered people and took out the receipt book. The peasants had to go there when he called them. They had to. The opposite would be unimaginable. There was nothing beneath the receipt, no carbon copy. How much is your tax? When it was three liras, he took five. But then he wrote down two on the receipt. See?

Before Mr. Tomruk finishes his sentence, another peasant Emin Necati Kırca adds:

The Black Hell... Bosça Bosça The Black Hell Bosça... He was the tax collector. He was old. Someone always announced the Black Hell's coming. He was a tough man; that's what people said. He was tough with the collection, too; people used to be afraid of him, yes. He even slapped people! That's what we used to hear from the others.

Gene Memet (Memet, the Mite) the tax collector from the Akseki/ibradı district, has the strangest story of all. A peasant, Ali Canbaş, about the tax collector's nickname, says:

...People used to call him Gene Memet... They called him Gene; he was known to be quite faithful to his job. Because he was good at his job and took it seriously, people gave him the nickname Gene.

On the other hand, Necla Duru, the daughter of one of Gene Memet's friends, cannot remember much about him and says:

He was from Akseki. I don't think I've ever heard his surname. I don't know why they called him this nickname, though. That's all I remember.

However, Hüseyin Gerçek gives us detailed information and narrates an interesting story as to the origins of Gene Memet's nickname:

There was a guy called Gene Memet, from İbradı. He often came, and I knew him... He was about $1.73-1.75 \mathrm{~cm}$ tall. I am $171 \mathrm{~cm}$ tall. He was about my size. He wasn't thin. His face was like that of a gibbon. Sometimes he wore a flat cap, and sometimes a trilby. Because he was from İbradı, we also used to frequent the borough - İbradı used to be a borough, not a town. So, that's how I know Gene Memet. He used to come with a stock book. He was a bit old, I think, or was he visually impaired? Not sure, but he wore glasses, I remember that. He wore his glasses and wrote the receipts... Whenever he was here, he stuck like glue ${ }^{5}$. (Laughs) That's why he was called Gene Memet. That's what I know. There used to be an elderly man here named Mehmet. He is long gone now. One day, as he was going home, someone said "Gene Memet is coming". Gene is not something nice, once it clings onto your skin, it won't leave you. And this other Mehmet, son of Ömer, takes the announcement personally and files a defamation lawsuit against this person who had announced the coming of Gene Memet. However, at court, the defendant defends himself by

\footnotetext{
4 The collector's surname in local dialect

${ }^{5}$ As a Turkish idiom, "kene gibi yapışmak" is translated as "stick like glue" into English; however, a literal, word-for-word translation would be "stick like a mite;" "mite" is "kene" [it is gene here in the local accent], hence the nickname.
} 
saying that what he meant was that "Mehmet was coming again. "The defendant was acquitted. Can you believe that? Yes, I did witness this incident.

\subsection{THE STORY OF SÜLEYMAN, THE BUTCHER}

The intriguing story of Süleyman, the Butcher (Kasap Süleyman) that was encountered during the interviews carried out for the purposes of this research in the Kalkan district is unique and has never been published in a written source before. In addition to its novelty, the story also provides a significant example in terms of the way local tax collection functions.

The story of Süleyman, the Butcher who wandered along with the tax collector when the cattle tax (ağnam vergisi) was still in effect has been confirmed and verified by almost every interviewee. The first person to narrate this story is Emin Necati Kırca:

...There used to be a Sucu [Waterman] Memet Efendi... He always came here with a butcher. If you possess cattle, you'll pay the tax. The guy was called Süleyman, the Butcher. He, Süleyman, the Butcher, was always with the tax collector. His full name was Süleyman Belli, I guess.

Another account that supports this version of the story belongs to Yusuf Ustaali:

Yes, yes, I know him. I know him, too. They used to go around together. You possess goods and not pay the tax? Süleyman, the Butcher was always with the tax collector. When the debtor failed to pay his taxes, the butcher guy purchased their animals. That's how it worked. I know them.

Sadık Yılmaz also tells us a similar story:

Süleyman, the Butcher was always with this tax collector man. The butcher purchased debtors' goats and gave the money to the collector.

As to the way this mechanism functions, Emin Necati Kırca adds the following to his story:

The collector comes to receive the tax, but there is no money. Once, he came to me. I had the cattle, but I didn't have the money. The butcher bought my cattle and took them away. He gave the money to the tax collector. That's how it worked.

Mehmet Kocasarı, on the other hand, says:

When I had 100 goats in the fold, I used to hide 50 of it. All you needed was to find a shepherd. Then, these guys came to collect taxes. The butcher said "Give me that one and that one, and that." He paid for them to the tax collector. And we were done.

Süleyman, the butcher seems to have underpriced the cattle, which was verified to a large extent in the interviews. Emin Necati Kırca comments on the butcher as follows:

Yes, he bought them. Of course, he did. Who else had the money to buy those cattle? Whatever price Süleyman, the Butcher gave was okay. It had to be.

Here, He also emphasises the desperation of peasants and how difficult it is for them to question certain things.

Nobody knows him.(Laughs). Because nobody dared to ask him anything. Nobody could. When the gendarme comes for you, you cannot question them. They just come and get you. It was the same with the butcher.

Mehmet Kocasarı's account is even more desperate:

... This man comes on horseback and commands you to gather the goats. He sets aside four of the goats. You have to obey. He never dismounts his horse.

${ }^{6}$ The Turkish words for 'mite’ and 'again’ are quite similar; respectively kene (gene here) and yine (also gine in colloquial Turkish). 
Complementary to the narrated story, Sadık Yilmaz comments on the relationship between the tax collector and the butcher as follows:

I heard that they worked together. I think they did.

Mehmet Kocasarı, however, says that such collaboration is out of question and adds that the butcher once talked to him. He notes:

No. No. No way. No way. There were no such rumours then. But we were happy when the tax collector came. We sent him word so he would come. What would you give the man? We need goats; we need money. We always sold our goats to pay our debts. Fortunately, we had goats or calves to sell. We had to sell something. What else could we do? See?

Although last two narratives are in contradiction and it cannot be easily said that collector and butcher work in agreement, it is true that Süleyman, the Butcher was a rich man and his richness seem to come from buying cheaper.

\subsection{CONCLUSION AND OVERALL ASSESSMENT}

It is well known that one of the fundamental relations between lord and peasants in ancient regime and state and citizens in modern nation state is surplus extraction or tax levy. The other type of relation is recruitment, associated with it, and both are problematical. There has been always a tension between ruler and subject and this tension lead to great upheavals or sometimes revolution as easily found in the history of nation state formation.

In his works Mann (1992; 1986) made a difference between despotic and infrastructural power and state power evolves from the first to the latter in a historical context. Although the parameter of the first type is violence, state try to find and put into practice more sophisticated way of extraction which can also be said rely on consent in second type.

From this perspective, results gathered from the interviews justify this evolution in Turkish case. In consideration of their ages, period which our respondents remembered is 1940s. This era can be characterized as despotic power and it can be said that practices of government under single party rule mostly rely on violence. When it is considered with Second World War conjuncture, it is expected that complain about taxes is in common as can be traced from whole of the tax payer's narratives.

After the 1950 election, oldest and founder party of the republic The Republican People's Party (CHP) lost its hegemony and Democratic Party (DP) came into power, it can be said that new era started. The sign of this new era which partly characterized as infrastructural power can be followed from narratives. Almost all tax payers' narratives, after complaining about heavy taxes, ended expression like "Democratic Party set our free". The fear which become concrete in nicknames is also related the period. It can be said that the condition of the period led to increase the fear although still in case especially in rural area.

\section{REFERENCES}

Danacıoğlu, E. (2010). Geçmişin İzleri: Yanıbaşınızdaki Tarih İ̧in Bir Klavuz, İstanbul: Tarih Vakfı Yurt Yayınları.

Mann, M. (1986). Source of Social Power Vol. 1: A History from Beginning to A.D. 1760, Cambridge: Cambridge University Press.

Mann, M. (1992). States, War and Capitalism, Oxford: Blackwell.

Neyzi, L. (2009). Ben Kimim: Türkiye'de Sözlü Tarih Kimlik ve Öznellik, İstanbul: iletişim Yayınları.

Perks, R., \& Thomson, A. (1998). The Oral History Reader, London and New York: Routledge.

Thompson, P. (2000). The Voice of the Past, Oxford: Oxford University Press. 